\title{
Peran Pola Komunikasi Orang Tua terhadap Perkembangan Emosi Anak Usia 4-5 di Masa New Normal
}

\author{
Zulfa Nailli Munna ${ }^{1} \bowtie$, Arwendis Wijayanti ${ }^{2}$, Octavian Dwi Tanto ${ }^{3}$ \\ Pendidikan Anak Usia Dini, Sekolah Tinggi Keguruan dan Ilmu Pendidikan Modern Ngawi, \\ Indonesia ${ }^{(1,2,3)}$
}

DOI: $10.31004 /$ obsesi.v6i1.1334

\begin{abstract}
Abstrak
Peran pola komunikasi orang tua dalam perkembangan anak sangat dibutuhkan, terlebih di masa new normal ini intesitas kebersamaan anak dengan orang tua menjadi lebih sering. Penelitian ini untuk mengidentifikasikan temuan peran pola komunikasi orang tua terhadap perkembangan emosi anak usia 4-5 tahun di TK Darmawanita Macanan 2, Kecamatan Jogorogo, Kabupaten Ngawi. Dengan mengamati anak 4-5 tahun yang merespon positif pembelajaran daring, metode penelitian studi kasus dengan pendekatan kualitatif, Miles and Huberman adalah teknik analisis data yang digunakan. Hasil penelitian menunjukkan dalam melakukan komunikasi bentuk pola komunikasi yang diterapkan orang tua adalah terbuka, kompromi dan support positif. Bentuk ini muncul karena adanya proses pola komunikasi seperti mengajak bermain anak, memberikan telling story, dan ice breaking yang menarik kepada anak. Adapun kesabaran orang tua, kreativitas orang tua, dan ketersediaan APE merupakan faktor yang mempengaruhi pola komunikasi orang tua yang baik dengan anak sehingga perkembangan emosi anak dapat berkembang dengan baik.
\end{abstract}

Kata Kunci: anak usia dini; pola komunikasi orang tua; emosi; peran; new normal

\begin{abstract}
The role of parental communication patterns in child development is very much needed, especially in this new normal era, the intensity of children's togetherness with parents becomes more frequent. This study is to identify findings on the role of parental communication patterns on emotional development of children aged 4-5 years at TK Darmawanita Macanan 2, Jogorogo District, Ngawi Regency. By observing children 4-5 years of age who respond positively to online learning, a case study research method with a qualitative approach, Miles and Huberman is the data analysis technique used. The results showed that in communicating the forms of communication patterns applied by parents were open, compromise and positive support. This form arises because of the process of communication patterns such as inviting children to play, giving interesting telling stories, and ice breaking to children. As for parental patience, parental creativity, and availability of APE are factors that influence good communication patterns between parents and children so that children's emotional development can develop properly.
\end{abstract}

Keywords: early childhood; parent communication patterns; emotions; role; new normal

Copyright (c) 2021 Zulfa Nailli Munna, Arwendis Wijayanti, Octavian Dwi Tanto

$\triangle$ Corresponding author:

Email Address : zulfanaillimunna@gmail.com (Jogorogo, Ngawi, Jawa Timur, Indonesia)

Received 6 May 2021, Accepted 22 May 2021, Published 1 June 2021 


\section{PENDAHULUAN}

Di masa new normal, dimana tidak memungkin pelaksanaan pembalajaran di sekolah mengharuskan pelaksanaan pembelajaran dilaksanakan dari rumah. Walaupun terdapat berbagai kendala yang ditemui seperti permasalah teknis ataupun adaptasi guru, anak dan orangtua yang sama sekali belum terbiasa dengan hal ini, dan tidak sedikit dari orang tua yang mulanya menolak dengan hal ini, karena mereka berasumsi kalau anak nantinya akan begitu bosan dan tidak dapat menyerap pembelajaran dengan baik selama belajar dari rumah. karena keterbatasan kemampuan orang tua dan fasilitas, terlebih di wilayah jogorogo jaringanpun sangat tidak stabil, tetapi terdapat fakta menarik bahwa selama pembelajaran dari rumah maka semakin banyaknya komunikasi yang terjalin antara anak dan orang tua sehingga memunculkan emosi yang baik dari anak, hal ini dapat timbul karena banyaknya waktu yang dihabiskan anak dengan orang tua.

Perkembangan emosional merupakan perkembangan yang mendasari dan sangat mempengaruhi perkembangan lainnya. Dalam penelitian (Kurniawan et al., 2017) dikemukakan bahwa emotional intelligence sangatlah penting agar kecerdasan kognitif dapat diarahkan. Penelitian lainnya yaitu penelitian (Naimah, 2019) yang mengungkapkan bahwa kecerdasan inteligensia bukan merupakan faktor penentu kesuksesan sesorang, tapi kesuksesan seseorang lebih dipengaruhi oleh kecerdasan emosional. Dapat kita lihat bahwa ketika kecerdasan yang berkembang baik tanpa diiringi dengan perkembangan kecerdasan emosional maka kecerdasan tersebut tidak akan sempurna. Seperti halnya ketika ada anak yang sangat unggul kognitifnya tetapi dia sangat kurang dalam perkembangan emosinya maka akan kalah dengan anak yang kemampuan kognitifnya biasa biasa saja tapi dia ungul dalam kecerdasan emosinya.

Walaupun banyak sekali kita temui penelitian yang membahas tentang hal-hal yang mempengaruhi perkembangan emosi anak tapi belum pernah ada penelitian yang membahas tentang peran pola komunikasi orang tua terhadap perkembangan emosi anak dimasa new normal. Ada sebagian penelitian yang hampir sama dengan penelitian ini yaitu penelitian dari (Kurniawan et al., 2017) memaparkan bahwa rendahnya pemahaman keluarga tentang peran komunikasi orang tua terhadap perkembangan emosi anak dapat dilihat dari seberapa tidak menganggap penting dan kurangnya pemahaman yang benar tentang keduanya, sedangkan perkembangan emosi anak akan bersifat positif apabila terdapat budaya komunikasi yang demokratis. Dari paparan ini dapat dilit bahwa fokus penelitian sama-sama kepada peran pola komunikasi yang diterapkan keluarga sehingga mempengaruhi perkembangan emosional anak, tetapi yang membedakan adalah subyek penelitiannya penelitian ini subjeknya remaja sedangkan penelitian yang dilakukan penulis subjeknya adalah anak usia 4-5 tahun.

Dalam pendidikan dan pengasuhan anak usia dini penelitian ini berkontribusi untuk bisa dijadikan role model pengasuhan anak usia dini di masa new normal. Dengan penelitian ini setidaknya para pengasuh anak usia dini kususnya orang tua dapat memahami dan menerapkan bentuk-betuk pola komunikasi yang bisa diterapkan sehingga dapat memicu perkembangan emosi anak. Hal ini didukung oleh penelitian (Kurniawan et al., 2017) yang menyatakan bahwa pola komunikasi yang diterapkan akan mempengaruhi perkembangan emosi. Sebenarnya bentuk bentuk pola komunikasi yang dipaparkan penulis sangatlah mudah untuk diterapkan tinggal para orang tua mau atau tidak untuk menerapkannya. Tapi seharusnya orang tua tidak ragu dalam menerapkan pola komunikasi yang positif tersebut terlebih sudah kita ketahui seberapa pentingnya perkembangan emosi yang akan mempengaruhi perkembangan lainnya.

Pentingnya perkembangan emosi anak dapat diamati dari beragamnya penelitian yang membahas secara spesifik dan beragam tentang perkembangan emosi diantaranya adalah hasil penelitian (Nurmalitasari, 2015) yang mengungkapkan bahwa perkembangan sosial emosial anak harus dilakukan sedini mungkin karena pada masa itu anak mulai 
bergaul dengan teman sebaya, sedangkan perkembangan sosial emosional anak sangat dipengaruhi oleh bagaimana orang tua atau orang dewasa disekitar merawatnya.

Ada banyak penelitian tentang peran pola komunikasi orang tua dan peningkatan perkembangan emosi anak di antaranya, penelitian yang pertama penelitian (Astuti, 2019) yang membahas tentang bagaimana hubungan antara pola komunikasi orang tua dengan kemampuan bicara anak ternyata didapatkan hasil bahwa keduannya memiliki hubungan yang signifikan dimana apabila orang tua dapat menerapkan pola komunikasi sesuai dengan tahap pola komunikasi yang sesuai, maka perkembangan bicara anak juga akan baik. Kedua adalah penelitian (Syukur \& Hamdani, 2017) yang menyatakan bahwa peran dan kepedulian orang tua sangatlah penting untuk anak, dimana dengan melakukan komunikasi intrapersonal yang dilakukan secara langsung sehingga feedback yang dihasilkan juga bisa langsung dilihat, yang mana pola komunikasi antara anak dengan orang tua diadakannya stimulus kepada orang yang diajak bicara disini anak dan yang dapat menimpulkan efek sehingga mampu meningkatkan prestasi belajar anak.

Penelitian ketiga adalah penelitian (Novela, 2019) yang memaparkan bahwa pola asuh dalam sebuah keluarga sangatlah penting dan ternyata peran seorang ayahpun juga tidak kalah penting dengan peran ibu, karena dengan adanya peran ayah dapat mempengaruhi perkembangan kognitif dan sosial emosional anak, karena dengan adanya peran ayah dapat memotivasi anak, ketika dari masing-masing orang tua apabila dapat menguasai dan melakukan perannya sesuai dengan semestinya maka anak akan merasa senang dan nyaman berkomunikasi dan berbaur dengan mereka, sehingga emosi yang dimunculkan anakpun juga positif. Penelitian keempat (Noor baiti, 2020) menyatakan bahwa adanya hubungan yang signifikan antara pola asuh dan pola komunikasi orang tua terhadap kemampuan bahasa anak, sehingga apabila pola komunikasi dan pola asuh yang diterapkan orang tua baik maka perkembangan bahasa anak juga baik pula, komunikasi pertama yang dilakukan anak adalah komunikasi dengan keluarga, tetapi perlu kita ketahui bahwa komunikasi yang dilakukan anak akan berbeda dengan komunikasi yang dilakukan orang dewasa, karena perbedaan aktivitas sehari-hari yang akan mempengaruhi intesitas mereka berkomunikasi, bercerita pengalaman sehari-hari dan bagaimana mereka mengungkapkan gagasan kepada orang tua.

Penelitian yang kelima adalah (Mulyani, 2017) menyatakan bahwa untuk merangsang kecerdasan emosi sangat memerlukan peran keluarga, karena pengalaman sosial ini sangat berimbas pada perilaku sosial anak selanjutnya yaitu dengan teman sebayanya, maka apabila ingin memunculkan emosi positif dari anak orang tua harus memperbaiki hubungan sosial dengan anak, hal ini dapat diwujudkan dengan menerapkan pola komunikasi yang baik dengan anak, agar ketika anak bersosialisasi dengan teman sebayanya emosi yang dibawa anak adalah emosi yang positif. Dari penelitian penelitian yang sudah dipaparkan di atas belum ada penelitian yang seperti investigasi ini, belum ada penelitian yang berpusat membahas tentang pola komunikasi orang tua yang mempengaruhi perkembangan emosi anak usia 4-5 tahun di masa new normal, sehingga penelitian dapat digunakan sebagai contoh yang baik untuk mengasuh anak-anak apalagi di masa tertentu sepertin masa new normal.

\section{METODOLOGI}

Metodologi yang digunakan dalam penelitian ini adalah kualitatif dengan menggunakan pendekatan study kasus. Adapun tujuan mengunakan metode ini adalah untuk mendapat gambaran yang lebih kompleks tentang focus penelitian yaitu peran pola komunikasi orang tua terhadap perkembangan emosi anak. Adapun subyek penelitian ini adalah anak-anak usia 4-5 tahun TK A Taman Kanak-kanak Dharmawanita Macanan 2 kecamatan jogorogo yang fokus pada satu anak yang memiliki respon positif dengan adanya daring, teknik pengambilan sampling dengan snowball sampling. Adapun penelitian ini dilakukan dalam kurun waktu 4 bulan. 
Penelitian ini menggunakan teknik analisis data Miles and Huberman. Yang mana teknik ini mencangkup reduksi data, penyajian data dan verifikasi data (Tanto, Octavian Dwi, 2020). Komponen dalam analisis data ini dapat digambarkan sebagai berikut;

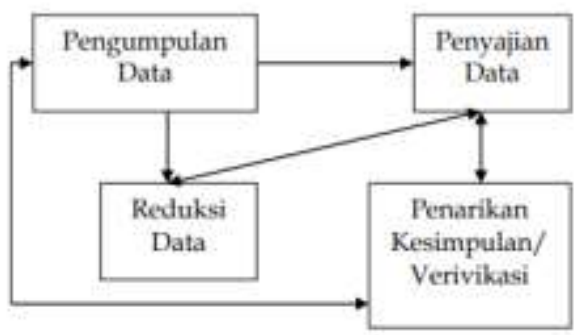

Bagan 1 Model InteraksiAnalisis Miles \& Huberman (Sugiyono, 2014)

Tahap pengumpulan data dalam penelitian ini adalah dengan dokumentasi, wawancara dan observasi . teknik pengumpulan data dokumentasi untuk mencari dan mengumpulkan video tentang pola komunikasi orang tua. Berhubung rumah peneliti dekat dengan subyek penelitian sangat memudahkan peneliti mengali informasi tentang subyek penelitian, adapun tahap pengumpulan data observasi dan wawancara digunakan sebagai pembuatan catatan lapangan bagaimana proses pola komunikasi yang telah diterapkan orang tua. Tahap reduksi data dengan merefleksikan, mengelompokkan dan memilah data yang sesuai dengan fokus penelitian ini. Adapun pemberian uraian singkat, bagan temuan dan sejenisnya ke dalam bentuk narasi masuk pada tahap penyajian data. Sedangkan memberikan penjelasan yang mengenai tema yang mencerminkan makna dari temuan penelitian ini.

\section{HASIL DAN PEMBAHASAN}

Berdasarkan hasil analisis data di lapangan, ditemukan bahwa terdapat bentuk pola komunikasi orang tua terhadap perkembangan emosi anak usia 4 sampai 5 tahun. Bentuk pola komunikasi yang diterapkan orang tua seperti terbuka, kompromi dan support positif merupakan komunikasi yang diterapkan orang tua terhadap anak, hal tersebut dapat dilihat sepanjang proses pola komunikasi yang diterapkan orang tua.

Bentuk pola komunikasi terbuka terlihat ketika orang tua memberikan kebebasan kepada anak untuk memilih belajar yang apa dulu, mereka tidak pernah memaksakan anak mengerjakan yang mana dulu, orang tua mengikuti mood anak, sehingga anak menjadi lebih senang, nyaman dan ringan dalam melakukan belajar, bahkan tidak jarang orang tua selalu mimta maaf karena sang anak akan telat mengirimkan pekerjaan saat hari itu, karena anak belum mau mengerjakan. Karena menurut orang tua memaksakan keinginan anak sangatlah tidak baik karena bisa juga akan membebani anak dan bisa-bisa membuat anak merasa tertekan dan mereka tidak mau membebani anak dengan itu.

Bentuk pola komunikasi yang lain adalah bentuk pola komunikasi support positif yang mana dapat dilihat ketika orang tua terutama ibu menemani anak dalam proses belajar dari rumah. Orang tua sangat mempertahankan kenyamanan anak dapat dilihat ketika orang tua menyiapkan semua alat belajar, seperti melancipi pensil warna, menjaga agar meja tetap stabil, ketika meja tidak stabil orang tua slalu menanyakan kepada anak, mejanya sudah stabil belum nak?, pewarnanya sudah enak belum nak?. Gambaran komunikasi tersebut dapat diilisutrasikan pada gambar 1 dan 2.

Terdapat bentuk pola komunikasi kompromi dapat dilihat ketika adanya kesepakatan atau kompromi antara anak dan orang tua, berdasarkan observasi ketika mood anak tidak baik orang tua menawarkan kepada anak apabila anak mampu menyelesaikan tugasnya hari ini maka anak akan dibuatkan lauk kesukaannya, dibuatkan mainan sederhana, dan terkadang juga dibelikan mainan sederhana yang murah tapi yang disukai anak. Dan ternya hal-hal sederhana ini dapat mengembalikan mood anak dengan sangat cepat. 


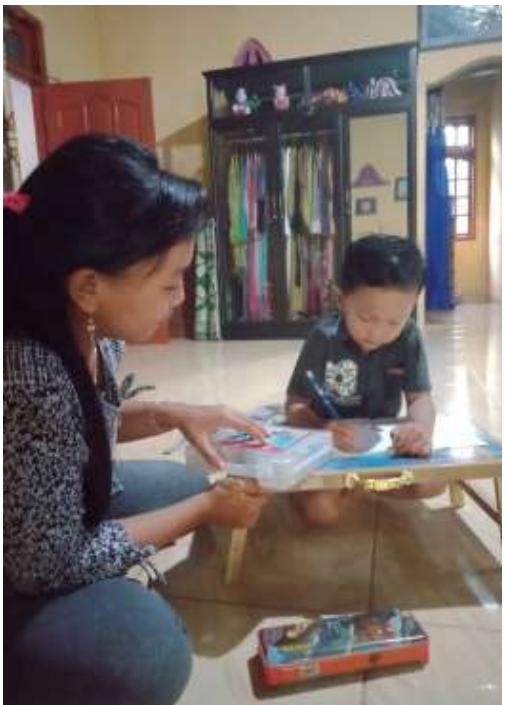

Gambar 1 orang tua membenarkan meja belajar anak

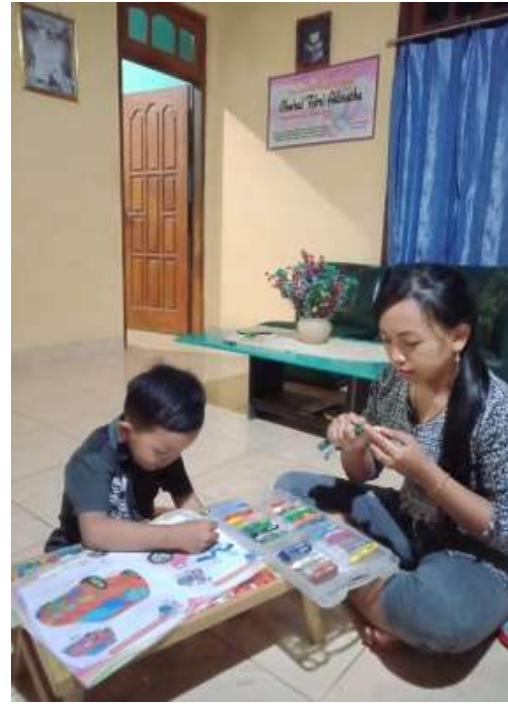

Gambar 2 orang tua membenarkan meja belajar anak

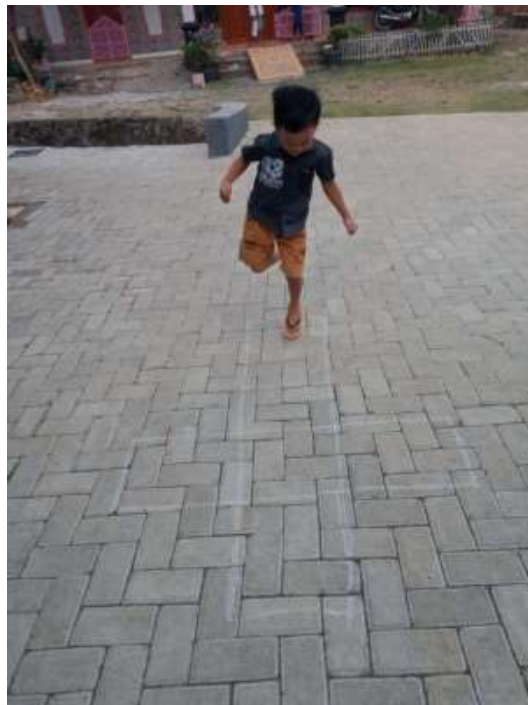

Gambar 3 anak sedang bermain mainan tradisional yaitu engklek

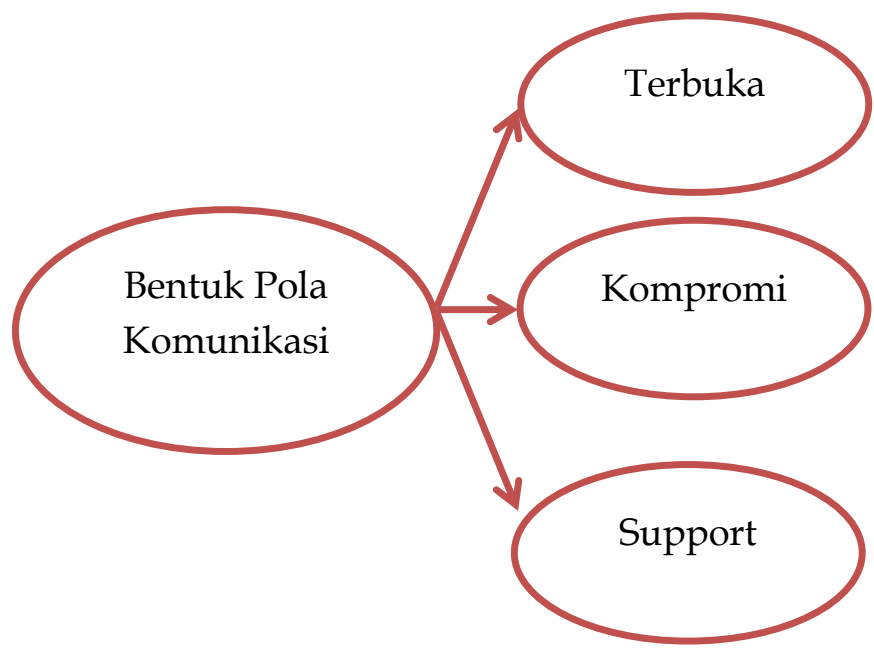

Bagan 2 bentuk pola komunikasi

Temuan tentang bentuk pola komunikasi orangtua terhadap perkembangan emosi anak dalam pembelajaran daring ini sebagaimana hasil penelitian (Tanto, 2021) yang mengungkapkan bahwa melalui pembelajaran daring orangtua dapat membangun ikatan emosi amannya dengan sang anak. Mendukung analisa di atas sumber lain menyatakan bahwa interaksi yang terjadi antara anak dan orangtua merupakan interaksi yang dapat mengembangkan aspek perkembangan emosi anak (Rahmawati, 2018).

Kontras dengan hasil penelitian di atas, hasil penelitian lain mengungkapkan bahwa terdapat dampak negative dari proses pembelajaran daring yakni munculnya perilaku intoleran yang muncul karena kurangnya kegiatan bermain bersama (Kusuma \& Sutapa, 2020). Bahkan hasil penelitian ini juga menyebutkan bahwa dampak dari proses pembelajaran ini anak juga mengalami kekerasan verbal karena proses belajar yang kurang lazim (Kusuma \& Sutapa, 2020).

Adanya hasil temuan yang berbeda ini menunjukkan bahwa positif atau negatifnya emosi anak dipengaruhi oleh bagaimana sentuhan kasah saying yang diberikan oleh orangtua. Sentuhan kasih sayang yang penuh cinta akan berdampak pada perkembangan emosi yang positif. Sebaliknya sentuhan kasih sayang yang penuh amarah akan berdampak pada perkembangan emosi negative. Keluarga merupakan ujung tombak dalam pembentukan 
pribadi anak karena keluarga mempunyai peranan yang paling penting dalam persoalan pendidikan anak, dan keluarga merupakan tempat tumbuh kembang anak mulai dari lahir hingga dewasa (Rahmah, 2018).

Temuan lain dari penelitian ini mendeskripsikan bahwa terdapat proses terbangunnya pola komunikasi orang tua yang positif terhadap anak usia 4-5 tahun. Terbentuknya pola komunikasi terlihat adanya proses pemberian telling story yang berisi motivasi dari orang tua hal ini terlihat ketika anak mengatakan bu aku capek, bu aku tidak bisa, bu itu terlalu sulit tapi orang tua tidak pernah memarahi anak justru mereka memberika motivasi kepada anak bahwa anak akan bisa mengerjakannya, dengan menyampaikan cerita yang mengandung motivasi tentang orang terdekat anak, ataupun cerita teman anak bisa tentang keberhasilan mereka, sehingga membuat anak bersemangat dan senang hati untuk menirukan hal-hal baik yang ada dalam cerita. Dan orang tua pun menghubungkan hal- hal tersebut untuk membuat anak semangat belajar.

Temuan ini sebagaimana hasil penelitian (Tanto et al., 2019b) yang mengungkapkan bahwa gaya bahasa merupakan faktor pendukung terbentuknya karakter positif anak. Sebagaimana karakter, emosi positif pada anak pun dapat dibentuk melalui pOla komunikasi verbal yang dilakukan oleh orangtua. Hasil penelitian (Adrianindita, 2015) mengungkapkan bahwa metode bercerita dapat digunakan sebagai media untuk meningkatkan kemampuan social emosional anak usia 2-3 tahun. Sumber lain menegaskan bahwa cerita dapat berdampak positif pada aspek sosial-emosional anak. Melalui kegiatan bercerita, orang tua dan guru dapat melatih emosi anak untuk meningkatkan kecerdasan emosional (Anwar Efendi, 2006).

Proses lain yang terlihat yaitu saat orang tua memberikan ice breaking di tengah" kejenuhan anak dalam melakukan pembelajaran di rumah, karena pembelajaran yang dilakukan dari rumah membuat mereka jarang bisa bermain dengan temannya dan monoton melakukan apa-apa di rumah sehingga membuat anak terkadang sangat bosan. Maka dari itu orang tua berinesiatif sering mengajak anak ice breaking conyoh ice breaking yang biasanya diberikan orang tua adalah mengajak tepuk sederhana, gerak dan lagu bersama.

Hasil penelitian (Rosyadi Leni D. A, 2019) menyebutkan bahwa ice breaking dapat mempengaruhi motivasi belajar pada kelompok B di TK Nurul Huda Krakahan, Tanjung, Brebes Tahun Ajaran 2018/2019. Ice breaking merupakan game yang dapat digunakan oleh guru untuk mengatasi kebosanan anak dan menstimulasi emosi positif anak pada situasi kegiatan pembelajaran. Senada dengan hasil temuan di atas, Sumber lain mengungkapkan bahwa ice breaking merupakan salah satu metode yang membantu anak untuk mengekspresikan perasaannya dan membangun sikap positif bagi dirinya serta temannya (Bakhtiar, 2015). Lebih lanjut temuan ini diilustrasikan pada gambar bagan 3.

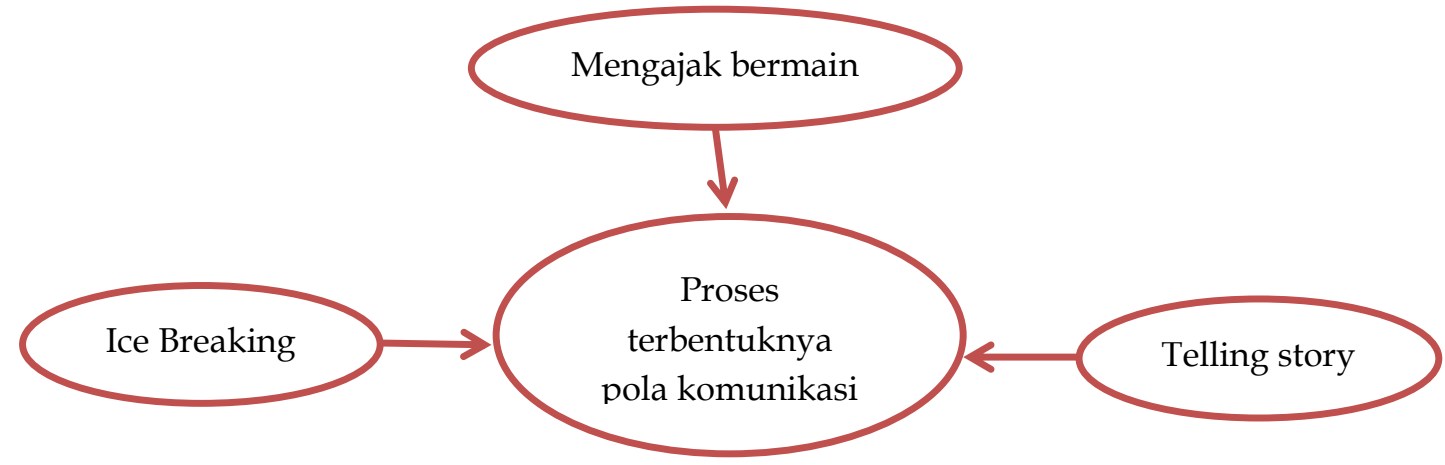

Bagan 3 proses terbentuknya pola komunikasi

Kesabaran orang tua sangatlah mempengaruhi perkembangan emosi anak karena bagaimanapun orang tua adalah contoh dari putra putrinya, dengan anak sering melihat orang tua sabar dalam menghadapi kenakalan mereka secara tidak sadar mereka akan menirukannya hal yang dilakukan orang tua ketika anak bersosialisasi dengan temna- 
temannya. Kesabaran orang tua sangat terlihat ketika anak merengkek tidak mau mengerjakan tugasnya tapi orang tua terus membujuk anak walaupun sesekali bisa mendapatkan mood anak membutuhkan waktu yang lumayan lama, tapi orang tua akan terus merayu anak dengan kata-kata lembut mereka sehingga anakpun luluh dengan kasih sayang orang tuannya. Temuan ini sebagaimana tercatat dalam sumber (Sofyan, 2019) yang mengungkapkan bahwa sabar merupakan salah satu bagian dari mindful parenting yang mencerminkan pola komunikasi positif dalam pengasuhan anak.

Kreativitas orang tua dalam memberikan pemahaman kepada anak ketika anak kurang mampu menerima informasi baru sangat mempengaruhi emosi anak, karena penyampaian orang tua yang baik dan bisa menyesuakan dengan tingkat pemahaman anak, terutama dengan bahasa anak, dan dihubungkan dengan hal-hal sederhana yang sudah anak paham dan dengan menghubungkan dengan hal-hal yang ada di sekitar anak, maka anak akan sangat mudah menerima informasi tersebut. Yang mulanya anak engan untuk mempelajarinya karena kemenarikan orang tua dalam penyampaian anak akan dengan senang hati menerima penjelasan dari orang tua. Seperti contohnya adek katanya kalau besar pengen jadi pilot, dulu pilot itu bisa mengemudikan pesawat karena dia belajar dengan rajin mengemudikan pesawat, nah kalau adek pengen jadi pilot mulai sekarang juga harus rajin dan harus semangat ya belajarnya. Temuan tentang kreatifitas orangtua ini mencerminkan hasil penelitian Tanto et al. (2019a) yang mengungkapkan bahwa melalui kreatifitas dalam membuat wayang kulit, kemampuan empati anak terstimulasi sepanjang dilibatkan dalam proses kerajinan dalam membuat wayang kulit.

Faktor pendukung pola komunikasi positif diantaranya adalah ketersediaan Alat Pembelajaran Edukasi (APE) di rumah. Orang tua terlihat memberikan APE ketika anak mulai merasakan kebosanan saat melakukan proses pembelajaran daring. Hal ini dilakukan orangtua dengan tujuan untuk mengembalikan emosi positif anak dalam melakukan kegiatan belajar secara virtual.

Hasil penelitian Padmi, dkk. (2014) mengungkapkan bahwa metode bermain dengan berbantuan kartu huruf dapat meningkatkan kemampuan social emosional anak TK B Indraprasta Kuta, dengan perolehan rata - rata nilai pada siklus I 69,51 dan pada siklus II 87,87 . Kartu huruf yang merupakan alat permainan edukatif dapat digunakan oleh praktisi untuk menstimulasi aspek social emosional anak. Sebagaimana hasil penelitian tersebut, hasil penelitian Novi Ade Suryani (2019) metode bermain permainan tradisional raba-raba dapat meningkatkan kemampuan sosial emosional anak kelompok A PAUD IT Islamic Centre Bengkulu dengan rata-rata nilai pada siklus I yakni 59,7\% dan siklus II yakni 88,25\%. Lebih lanjut, temuan ini secara teknis diilustrasikan pada gambar bagan 4 .

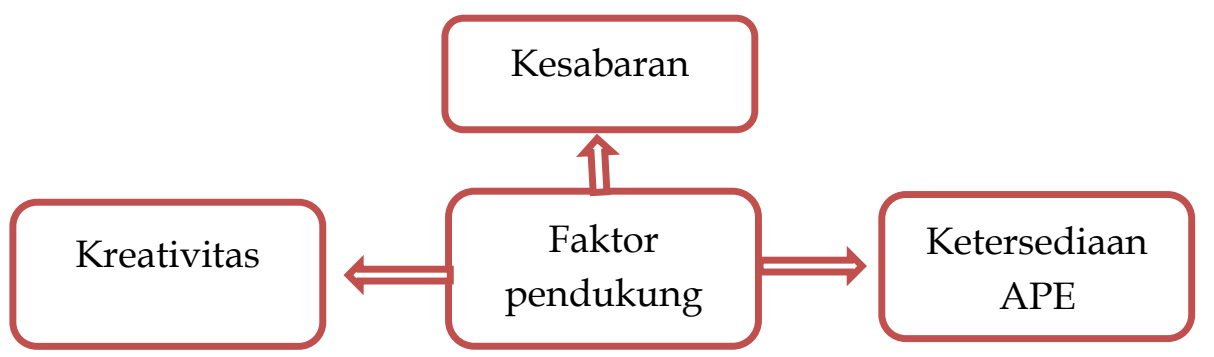

Bagan 4. Faktor pendukung pola komunikasi positif

\section{SIMPULAN}

Beberapa bentuk pola komunikasi orang tua seperti terbuka, kompromi dan support. Bentuk pola komunikasi orangtua ini terbentuk karena adanya proses pola komunikasi orang tua seperti mengajak bermain, telling story dan ice breaking. Adapun reward, kesabaran orang tua, kreativitas orang tua dan ketersediaan APE merupakan faktor yang mendukung terbentuknya emosi positif anak. 


\section{UCAPAN TRIMAKASIH}

Puji syukur atas kehadirat Tuhan yang telah melimpahkan rahmat dan taufikNYA sehingga penulis mampu melaksanakan dan menyelesaikan penelitian ini sebagaimana yang diharapkan. Trimakasih kepada kepala sekolah, guru, siswa dan orang tua siswa Taman Kanak-kanak Dharmawanita macanan 2 Kecamatan Jogorogo kabupaten Ngawi yang telah memberikan berbagai dukungan dan fasilitas dalam pelaksanakan penelitian ini dari awal sampai akhir. Ucapan trimakasih penulis sampaikan kepada tim editor Jurnal Obsesi yang telah memberikan kesempatan, kritik, saran, dan rekomondasi untuk perbaikan artikel ini.

\section{DAFTAR PUSTAKA}

Adrianindita, S. (2015). Upaya Meningkatkan Keterampilan Sosial-Emosional Anak Usia 2-3 Tahun Melalui Metode Bercerita Di Kb Siti Sulaechah 04 Semarang. Early Childhood Education Papers (Belia), 4(2), 32-37.

Anwar Efendi. (2006). Mengembangkan Kecerdasan Emosional Anak melalui Kebiasaan Bercerita (Dongeng). Jurnal Alternatif Pemikiran Kependidikan INSANIA, 11(3). https://doi.org/10.24090/insania.v11i3.201

Astuti, T. (2019). Hubungan pola komunikasi orangtua terhadap perkembangan berbicara anak di taman kanak-kanak. 3(November 2018), 88-95. https:// doi.org/10.29210/3003254000

Bakhtiar, M. I. (2015). Pengembangan Video Ice Breaking Sebagai Media Bimbingan Konseling Dalam Meningkatkan Keterampilan Sosial. Jurnal Psikologi Pendidikan Dan Konseling: Jurnal Kajian Psikologi Pendidikan Dan Bimbingan Konseling, 1(2), 150. https://doi.org/10.26858/jpkk.v1i2.1816

I Gusti Ayu Padmi, Nyoman Dantes, I. M. S. (2014). Efektivitas Implementasi Metode Bermain Berbantuan Media Kartu Huruf Untuk Meningkatkan Kemampuan Membaca Gambar Dan Sosial Emosional Anak. E-Journal Program Pascasarjana Universitas Pendidikan Ganesha, 4(11), 1-12.

Kurniawan, E., Artita, F. A., \& Asri, D. N. (2017). Kajian Problematika Pola Komunikasi Dan Perkembangan Emosi Remaja Pada Keluarga Un-. Prosiding SNBK (Seminar Nasional Bimbingan Dan Konseling, 1(1), 126-133.

Kusuma, W. S., \& Sutapa, P. (2020). Dampak Pembelajaran Daring terhadap Perilaku Sosial Emosional Anak. Jurnal Obsesi : Jurnal Pendidikan Anak Usia Dini, 5(2), 1635-1643. https://doi.org/10.31004/obsesi.v5i2.940

Mulyani, N. (2017). Upaya Meningkatkan Perkembangan Sosial Emosional Anak Usia Dini. Jurnal Ilmiah Mahasiswa Raushan Fikr, 3(1), 133-147. https://doi.org/10.24090/jimrf.v3i1.1013

Naimah, K. (2019). Mengembangkan Kecerdasan Sosial Emosional Anak Usia Dini Melalui Kegiatan Makan Bersama di Sekolah. El-Wasathiya: Jurnal Studi Agama, 7(1), 63-85.

Noor baiti. (2020). Pola Asuh dan Komunikasi Orang Tua Terhadap Perkembangan Bahasa Anak. PAUD Lectura: Jurnal Pendidikan Anak Usia Dini, 4(01), 42-50. https:// doi.org/10.31849/paud-lectura.v4i01.4959

Novela, T. (2019). Dampak Peran Ayah Terhadap Perkembangan Emosional Anak Usia Dini. Raudhatul Athfal: Jurnal Pendidikan Islam Anak Usia Dini, 3(1), 16-29. https://doi.org/10.19109/ra.v3i1.3200

Novi Ade Suryani. (2019). Kemampuan Sosial Emosional Anak Melalui Permainan Raba-Raba Pada Paud Kelompok A. Jurnal Ilmiah Potensia, 4(2). https:// doi.org/10.33369/jip.4.2.141-150

Nurmalitasari, F. (2015). Perkembangan Sosial Emosi pada Anak Usia Prasekolah. Buletin Psikologi, 23(2), 103. https:// doi.org/10.22146/bpsi.10567

Rahmah, S. (2018). Pola Komunikasi Keluarga dalam Pembentukan Kepribadian Anak St. Rahmah UIN Antasari Banjarmasin. Jurnal Alhadharah, 17(33), 13-31. https:// doi.org/10.18592/alhadharah.v17i33.2369 
Rahmawati, G. M. (2018). Pola Komunikasi Dalam Keluarga. Kajian Ilmu-Ilmu Komunikasi Dan Bimbingan Islam, 11(2), 163-181.

Rosyadi Leni Dwi Anggun. (2019). Pengaruh Ice Breaking Terhadap Motivasi Belajar Anak Pada Kelompok B Di Tk Nurul Huda Krakahan, Tanjung, Brebes Tahun Ajaran 2018/2019.

Sofyan, I. (2019). Mindful Parenting: Strategi Membangun Pengasuhan Positif dalam Keluarga. Journal of Early Childhood Care and Education, 1(2), 41. https://doi.org/10.26555/jecce.v1i2.241

Sugiyono. (2014). Metode Penelitian Pendidikan Kuantitatif, Kualitatif, dan R \& D. Alfabeta.

Syukur, M., \& Hamdani. (2017). Pola Komunikasi Interpersonal Orang Tua Dengan Anak Dalam Meningkatkan Prestasi Belajar Anak. Ilmiah Mahasiswa FISIP Unsyiah, 2(November), https://doi.org/10.34010/common.v2i2.1191

Tanto, Octavian Dwi, A. H. S. (2020). Stimulasi Perkembangan Motorik Halus Anak Usia Dini dalam Seni Tradisional Tatah Sungging. Jurnal Obsesi, 4(2), 587-586. https://doi.org/10.31004/obsesi.v4i2.421

Tanto, O. D. (2021). Pembentukan Kelekatan Aman Orangtua Pada Anak Usia Dini Dalam Pembelajaran Daring. Journal of Childhood Education, 5(1), 130-146. https://doi.org/https://doi.org/10.30736/jce.v5i1.503

Tanto, O. D., Hapidin, H., \& Supena, A. (2019a). Keterampilan Sosial Pengrajin Tatah Sungging Cilik Kepuhsari. Proceedings of the ICECRS, 2(1), 83. https://doi.org/10.21070/picecrs.v2i1.2405 https://doi.org/10.21070/picecrs.v2i1.2405

Tanto, O. D., Hapidin, H., \& Supena, A. (2019b). Penanaman Karakter Anak Usia Dini dalam Kesenian Tradisional Tatah Sungging. Jurnal Obsesi : Jurnal Pendidikan Anak Usia Dini, 3(2), 337. https://doi.org/10.31004/obsesi.v3i2.192 